\title{
Historical forest changes in the western United States
}

\author{
by Craig Loehle ${ }^{1}$
}

\begin{abstract}
Changes in factors such as temperature, precipitation, fire regimes, ozone, atmospheric $\mathrm{CO}_{2}$, and nitrogen deposition may have altered forest growth over the past century. Determining changes in forest growth over long intervals is complicated by constantly changing growing conditions due to tree maturation, stand self-thinning, disturbance, and other factors. Because a comprehensive review is lacking, results from publications examining forest growth trends in the western United States over the past 100 years were evaluated. Across the region, upper elevational forest ecotones have been expanding upward in many but not all locations, possibly due to warming and reduced snowpack. Across most of the region, both growth increases and decreases are localized and spatially dispersed. For the inland West, historical photography and long-term inventory data show clear densification and expansion of ponderosa pine (Pinus ponderosa) and mixed conifer forest across the region, mostly due to reduced fire incidence. However, a recent drought, probably linked to ocean cycles and exacerbated by warming, has caused a growth setback and mortality, especially in the Southwest. Forest densification due to altered fire regimes does not equate to enhanced growth per se. Aspen (Populus tremuloides) dieback has been noted due to recent drought and local conifer mortality caused by drought has also been documented in several locations. Regeneration after recent fires appears to be inadequate in many localities. Except for local increased growth at some high elevation and coastal sites and possible periodic drought effects in the Southwest, it is difficult to detect any growth trends with available data.
\end{abstract}

Key words: climate change; environmental factors; forest growth and yield; forest growth trends; inventory data; treeline; western United States

\section{RÉSUMÉ}

Les modifications relevées au niveau des facteurs comme la température, les précipitations, les régimes des feux, l'ozone, le carbone et l'azote atmosphériques, peuvent avoir affecté la croissance des forêts au cours du dernier siècle. L'identification de ces changements au niveau de la croissance des forêts au cours de longues périodes de temps est complexe du fait des conditions de croissance sans cesse modifiées par la maturation des arbres, l'auto-éclaircie des peuplements et d'autres facteurs. Compte tenu de l'absence d'un examen complet de la littérature, les résultats des publications portant les tendances de la croissance des forêts dans l'ouest des États-Unis au cours des 100 dernières années ont été évalués. Partout dans cette région, les écotones forestiers d'altitude supérieure se sont développés vers les sommets dans plusieurs mais pas dans tous les sites, possiblement à la suite du réchauffement et de la diminution du couvert de neige. Dans la majeure partie de la région, tant la croissance que la réduction de la croissance se sont avérées être spatialement localisées et dispersées. Dans le cas de la partie intérieure de l'Ouest, les photographies d'archives et les données d'inventaire à long terme indiquent une densification évidente et une expansion marquée du pin ponderosa (Pinus ponderosa) ainsi que des forêts résineuses mélangées dans toute la région, probablement par suite de la réduction de l'incidence des feux. Cependant, une sécheresse récente découlant probablement des cycles océaniques et amplifiée par le réchauffement, a provoqué un recul de la croissance et de la mortalité, spécialement dans le Sud-Ouest de la région. La densification forestière découlant de la modification des régimes de feux ne signifie pas implicitement une croissance accrue. Le dépérissement du tremble (Populus tremuloides) a été noté à la suite de la récente sécheresse et la mortalité des conifères a été relevée dans plusieurs localités. La régénération apparue après les récents feux de forêt semble être inadéquate sur plusieurs sites. Mis à part une croissance accrue localement à des altitudes plus élevées ainsi que sur des sites de la Côte ouest, et des effets probables des sécheresses périodiques dans le Sud-Ouest, il est difficile d'identifier les tendances de croissances à partir des données disponibles.

Mots clés : changement climatique, facteurs environnementaux, croissance et rendement des forêts, tendances de croissance forestière, données d'inventaire, ouest des États-Unis

\footnotetext{
${ }^{1}$ National Council for Air and Stream Improvement (NCASI), Naperville, IL, 60564, USA; Correspondence: cloehle@ncasi.org
} 


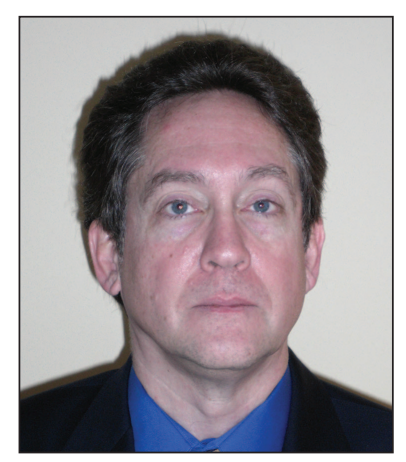

Craig Loehle

\section{Introduction}

Forest health is of critical interest to the public, forest landowners, and the forest products sector. Many studies have reported changes over the past century in climaterelated and other environmental factors that have the potential to influence forest health and growth, such as fire frequency, ozone levels, nitrogen deposition, atmospheric $\mathrm{CO}_{2}$ concentrations, temperature, and precipitation (Loehle et al. 2016). The magnitude and pattern of reported changes in some of these factors have varied regionally. For example, Pederson et al. (2015) reported that the 20th century has been anomalously wet in the eastern US. Kim et al. (2012) detected increasing nonfrozen seasons for Northern Hemisphere soil during 1979 to 2008. Mote et al. (2018) and Bishop et al. (2019) documented long-term winter drying in the mountainous west whereas Siler et al. (2018) documented stable snowpack since the 1980s. Bishop et al. (2019) also found spring increases in precipitation in western coastal regions of the US. A 431-year reconstruction of western Colorado snowpack from tree rings (Woodhouse 2003) did not reveal any trends. Because of the multiplicity of potential causal pathways and interactions, general discussions of effects of environmental changes on forests (e.g., Peñuelas et al. 2013), such as the benefits to tree growth from nitrogen $(\mathrm{N})$ or phosphorous $(\mathrm{P})$ deposition or from rising $\mathrm{CO}_{2}$, how multiple factors have been interacting to affect tree growth cannot be deduced from first principles but is rather an empirical question.

Various authors (Allen et al. 2010, 2015; Anderegg et al. 2015; McDowell and Allen 2015; McDowell et al. 2016) have predicted that changing conditions will lead to widespread forest mortality and/or dieback, especially in drier forest types, and may already be doing so. On the other hand, global surveys combining various types of data suggest that, on average, forest growth is increasing (e.g., Boisvenue and Running 2006; Campbell et al. 2017; Pretzsch et al. 2017). Schulte-Uebbing and de Vries (2017) and Wang et al. (2017) showed that $\mathrm{N}$ and $\mathrm{P}$ depositions have been increasing forest growth worldwide. These studies sometimes do not separate forest regrowth (e.g., after fire) or forest age effects from growth rate changes per se.

The contradiction between predictions that changing conditions should be having adverse effects on forests and evidence to the contrary needs resolution. It clearly affects estimates of current and future forest health, the status of forest resources, carbon sequestration, and effects on wildlife habitat and other ecosystem services. The question of forest health is particularly acute in the western US, where recent drought, insect outbreaks, and large fires have caused widespread tree mortality. This region is thus the focus of this review. Two companion reviews cover Canada (Loehle and Solarik 2019) and the eastern United States (Loehle, In Review).

Given a warming planet, what historical trends might be expected? At a coarse scale, one might expect a rise in the treeline and infilling of patchy, high-elevation forest. How- ever, treeline climates are complex. Aspect and exposure to wind can alter growing conditions in addition to temperature effects alone. Rising $\mathrm{CO}_{2}$ might be expected to increase tree growth (angiosperms more than gymnosperms) and increase drought tolerance via a rise in water use efficiency (Loehle et al. 2016). There is some global evidence for this (Gedalof and Berg 2010). Rising temperatures could increase growth in regions that are not water-limited, such as some coastal forests in the Pacific Northwest of the US (Loehle 2018). In contrast, at dry ecotones (usually lower elevations in the West), warming and/or drying could lead to reduced growth and range retreat upslope via drought, insect, or fire-caused mortality (citations above; Loehle et al. 2016). All these processes are spatially distributed and may be gradual, making change detection difficult.

Several types of historical data exist which may be used to reconstruct long-term forest changes. Historical photography can be compared to recent images to assess major changes. Fire scar data can be used to assess historical fire size and frequency. Forest surveys and permanent plots can be used to assess changes in density, biomass, and species composition and their relationship to climate. For treeline, age of regeneration with distance from the forest edge can be used to assess invasion rates. Pulses of tree establishment can be related to climate.

Remote sensing data can provide information on forest growth rates. However, some serious inconsistencies have been found between and within (over time) remote sensing products (e.g., Guay et al. 2014; De Kauwe et al. 2016; Jiang et al. 2017) and between remote sensing results and Earth system model calculations (Smith et al. 2016). For these reasons, remote sensing studies of trends are not evaluated here.

Fire has historically been an important governing force determining forest/shrub or forest/grassland ecotone boundaries. Decreased fire frequency or intensity can allow forest to expand at the dry range limit and become denser. Historically, fires in North America, and the West in particular, were more common 100 years or so ago due to recent fire suppression (Doerr and Santín 2016; Taylor et al. 2016; Addington et al. 2018; Klimaszewski-Patterson et al. 2018). Nineteenth century fire regimes in much of the drier West appear to have been dominated by frequent, low-intensity fires (Hagmann $e t$ al. 2013; O'Connor et al. 2014; Margolis and Malevich 2016; Swetnam et al. 2016; and citations below). The National Interagency Fire Center (https://www.nifc.gov/fireInfo/fireInfo_stats_totalFires.html) shows that recent decades exhibit fewer acres burned than the early $20^{\text {th }}$ Century, though early data is less reliable. Compared to the period 1970-1999, the most recent 17 years have roughly twice as many burned acres per year according to this database (see also Singleton $e t$ al. 2019). I attempt below to distinguish fire impacts on ecotones from other causes.

Because of changes in precipitation, temperature, fire regimes, $\mathrm{CO}_{2}$, and other factors, attribution of changes can be complex and often requires evaluation of several types of evidence. In the studies described next, more than one environmental factor often could have caused the observed changes in forest area or growth rates. In such cases, authors sometimes made inferences from historical data on climate (e.g., seasonal/annual changes in temperature/precipitation) and/or fires to help clarify causation. 


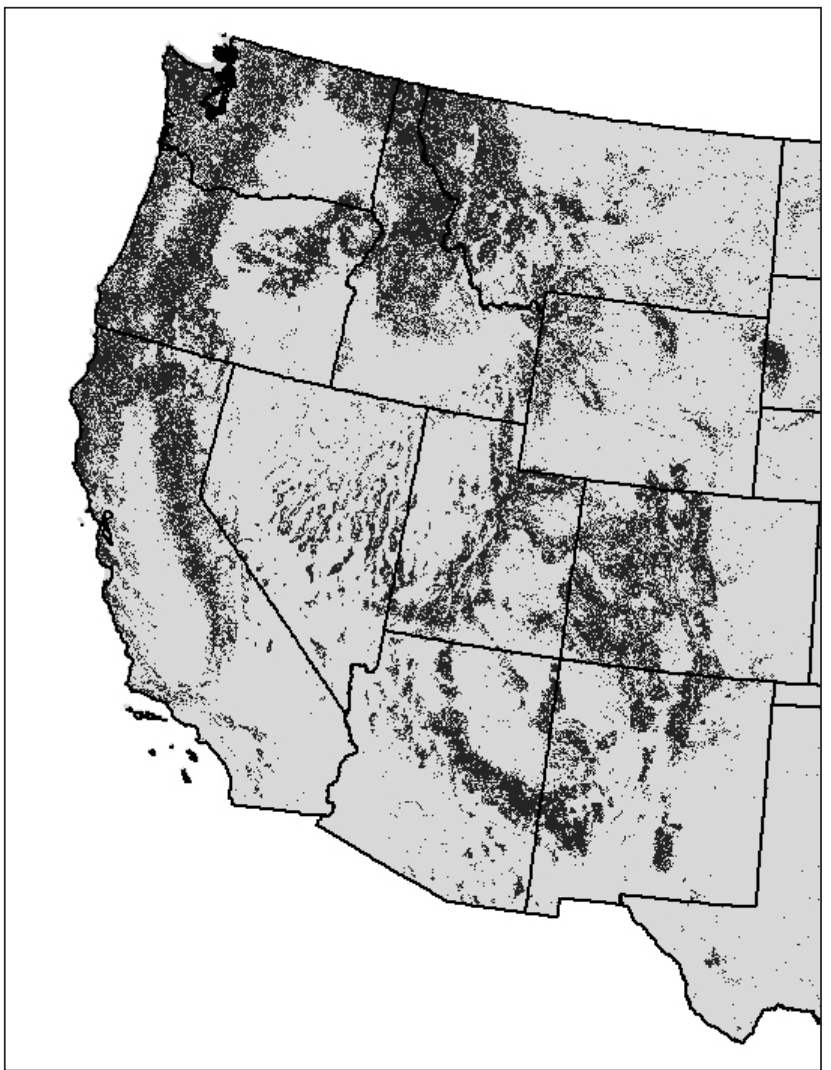

Fig. 1 Study area. Stippling indicates forest. Different forest types form local zonations at fine scales as a result of topographic moisture and temperature gradients

\section{Study area}

The study area was the western United States (Fig. 1). In this mountainous region, topography plays a key role in forest presence. Precipitation arrives mostly from the west, leading to high tree productivity in the coastal Pacific Northwest. Precipitation declines to the south and inland. Orographic effects lead to moisture gradients with elevation which, in concert with temperature gradients, lead to dry pine (Pinus spp.) forest at low elevations and to the south, and moister forest types at higher elevations, with rain shadow effects on the east side of mountain ranges. At higher elevations in the higher mountains, cold and snow create alpine treelines. Lower interior elevations (e.g., the Great Basin) are generally not forested due to dryness. Summers across the region tend to be dry. The continental climate means that local temperatures tend to be dominated more by altitude than latitude (Rochefort et al. 1994).

Across the West, a limited set of tree species and forest ecotypes dominate. At lower elevations where it is hotter and drier, ponderosa pine (Pinus ponderosa Dougl. ex P. \& C. Laws.) is found across the region, with some lodgepole pine (P. contorta Dougl. ex Loud.) and quaking aspen (Populus tremuloides Michx.) on sites that have burned. Moving upslope to cooler zones, Douglas-fir (Pseudotsuga menziesii (Mirbel) Franco), true firs (Abies spp.), and hemlock (Tsuga heterophylla (Raf.) Sarg. and T. mertensiana (Bong.) Carrière) dominate. The subalpine zone is comprised of silver fir
(A. amabalis (Dougl. ex Loud.) Dougl. ex J. Forbes), limber pine ( $P$. flexilis James), subalpine fir (A. lasiocarpa (Hook.) Nutt.), and Englelmann spruce (Picea engelmannii Parry ex Engelm.). In the very wet Washington coastal zone, hemlock and Sitka spruce (P. sitchensis (Bong.) Carrière) join Douglas-fir. Many other species, e.g., sugar pine, $P$. lambertiana Dougl. and western white pine, P. monticola Dougl. ex D. Don) are minor components or are locally abundant. The same dominant species span the entire zone and respond mainly to elevation and rainfall gradients, creating consistent elevational bands and sometimes large mono-specific stands (Burns and Honkala 1990).

\section{Methods}

The scientific literature was searched for references to longterm growth trends of forests in the western US. Woodlands and shrublands were considered out of scope. As an initial entry to the literature, the complete contents of Forest Science (2015-2018), Canadian Journal of Forest Research (2014-2018), Forest Ecology and Management (2013-2018), Global and Planetary Change (2014-2018), and Global Change Biology (2012-2018), (over 6000 articles), were manually searched for all papers that might touch on growth trends, mortality trends, or geographic trends, and then the literature was searched in Google Scholar using "alpine treeline", "forest history", "carbon sequestration", "forest NPP", "forest inventory", "forest greening", "forest browning", "forest dieback", "forest mortality", and "forest growth" as keywords. The International Tree-Ring Data Bank (ITRDB) was also searched. The cited literature in each publication identified in the searches was then searched.

\section{Results}

Seventy-seven relevant publications were located. Fourteen studies documented changes in forest extent or density, 27 documented elevational expansion, 15 addressed changes in mortality, six documented regeneration trends, two studied geographic range shifts, and 13 evaluated changes in growth rates. Multiple studies were found that evaluated tree-ring records but most were trying to reconstruct historical climate or hydrologic signals and did not contain data on growth trends per se. Thus, they could not be used. Because different approaches yield different types of information, the literature was next summarized by type: changes in extent; changes in mortality; and growth trends.

\section{Changes in forest ecotones, area, and density}

The most common response of forests globally over the past $100+$ years has been expansion and/or densification (Stevens et al. 2017; Nelson and Reams 2017). Expansion at cold margins can be an indication of warming or altered precipitation but, at dry margins, could result from fire regime changes, $\mathrm{CO}_{2}$ enrichment, precipitation increases, grazing changes, or some combination of these factors. Adult trees and seedlings may not respond the same to changing conditions. Blowing ground snow can kill seedlings but, once they are tall enough, this effect diminishes. Snowpack may prevent seedling establishment (Franklin et al. 1971) while the same snow aids adult trees via melt during the summer.

Millar et al. (2015) found that at multiple sites across four mountain ranges in the western Great Basin, upper elevation 
pines had experienced a pulse of recruitment between 1963 and 2000 for limber pine and between 1955 and 1978 for bristlecone pine (P. longaeva D. K. Bailey). Pines were found to have expanded above the current treeline, downslope into grass or shrub communities, and laterally at mid-slope into treeless zones. Average extension over all cases was $225 \mathrm{~m}$. These recruitment pulses were correlated with complex, lagged responses to increases in precipitation and higher minimum temperatures at those times. Smithers et al. (2018) found these same two species to be expanding their ranges, especially limber pine, which is expanding on all sites across the Great Basin.

Several studies at Glacier National Park, Montana, found contrasting results. Bekker (2005) found rates of advance of alpine treeline linear features (ribbon forest) of 0.28 to 0.62 $\mathrm{m} / \mathrm{y}$, with an establishment pattern of extension dating back to the 1700s. More recent establishment was farther downwind of existing trees than in the past. Butler et al. (1994), using historical photography, found mostly stable alpine treeline ecotones, with some increase in tree size and some seedling establishment upslope. Klasner and Fagre (2002) found visible thickening of tree patches but no ecotone shift in the same park. Alftine et al. (2003) found alpine forest expansion but not after 1980. Butler and DeChano (2001), also using historical photography at the park, found rates of lateral infilling of up to $9 \mathrm{~m} / \mathrm{y}$ and expansion upward of 1.5 to $4 \mathrm{~m} / \mathrm{y}$. These contrasting results in the same location no doubt reflect complex topographic effects on disturbance, exposure, wind, soils, and differences due to methods.

Several additional studies show rising treelines across the West. Moore and Huffman (2004) found tree encroachment onto meadows on the North Rim, Grand Canyon National Park, Arizona at rates of $0.35-0.47 \mathrm{~m} / \mathrm{y}$ over the period 1930 2004. On the Colorado Front Range, Daley and Shankman (1985) found some evidence of seedling advance. As this study is 34 years old, a revisit to this site might be informative. In Lassen Volcanic National Park, California, Taylor (1995) found that trees had been expanding since the mid1800s. Seedlings became established preferentially in years of low snowpack and warmer temperatures, but established trees did better with elevated temperature and precipitation. The patchy expansion was mostly on the order of $100 \mathrm{~m}$ over the period since the mid-1800s. An unusual case exists in the Valles Caldera, New Mexico (Coop and Givnish 2007) where lower elevation meadows are subject to cold air drainage such that trees are limited at both upper and lower elevations by cold, though changes in fire regimes may have also contributed to forest expansion. Based on aerial photography in 1935 and 1996, they found that meadows had decreased by $18 \%$ over the period, or $0.3 \% / y$. Additional studies have documented tree invasion of alpine meadows or expansion of the treeline in California (DeBenedetti and Parsons 1979; Vale 1981; Helms 1987; Taylor 1990; Millar et al. 2004), Colorado (Billings 1969; Shankman and Daly 1988), New Mexico (Dyer and Moffett 1999), Oregon (Franklin et al. 1971; Halpern et al. 2010; Haugo and Halpern 2010; Rice et al. 2012), Washington (Franklin et al. 1971), and Wyoming (Dunwiddie 1977; Vale 1978; Jakubos and Romme 1993; Moir et al. 1999;). Note that none of the studies cited here randomly sampled meadows or clearings to obtain an estimate of frequency of invasion. Rather, these studies were focused on the invasion process where it was found. The studies were, however, clear that invasions they documented were in areas devoid of signs of recent occupation by trees (i.e., not recent burns). In some cases, authors did note that not all treelines were extending. For example, Dyer and Moffett (1999) in New Mexico found that south slopes in sprucefir forest had been continuously invaded since the 1930s but that northeast slope ecotones were stable over this period.

It is generally believed that fire was historically rare in wet, high elevation forests of the West and, if it occurred, it was high intensity. Reilly and Spies (2016) documented this rarity in a large dataset for Oregon and Washington. DeRose and Long (2012), for example, documented historical drought and high-intensity fires in subalpine forests in southern Utah. Sibold and Veblen (2006) documented that high intensity subalpine fires in the Colorado Front Range since 1650 were related to oceanic cycles such as the Pacific Decadal Oscillation (PDO). However, it has been found that, at least in the Jemez Mountains of New Mexico, the moist mixed conifer forests did experience periodic low-intensity fires (Margolis and Malevich 2016). Such low-intensity fires could have created or helped maintain the upper treeline and high elevation meadows. However, data are sparse on this issue. Fire in upper treeline forests seems most likely to have played a role in maintaining meadows where upper elevation forests are still rather dry, such as at the Grand Canyon sites studied by Moore and Huffman (2004) or in Lassen Volcanic Park, California (Taylor 1995). Where alpine meadows are bordered by mature fire-sensitive species (e.g., Abies spp., Tsuga spp.), fire-maintained meadows seem unlikely. Some alpine meadows are clearly maintained by persistent snow (Billings 1969) and wet meadows may even resist fire except in the driest years (DeBenedetti and Parsons 1979). Finally, large alpine fires may result in long-lasting meadows due to slow reinvasion (Shankman and Daly 1988). Further subalpine fire history reconstructions would be useful.

Multiple studies across the West have documented increased forest density and infilling in drier forest types. Brown et al. (2015) reconstructed forest age structure in the northern Front Range, Colorado, using tree-ring analysis. Fire history was reconstructed from 1667 to 2012. Fires were recorded in two or more plots during 1667-1859 (the date of the last such fire) on average every 8-15 years. In 1860 (the earliest that stand structures could be reconstructed), all trees were ponderosa pine and stand density was highly variable. Forests in 2012 were denser, had higher basal area, more smaller trees, and more Douglas-fir and Rocky Mountain juniper (Juniperus scopulorum Sarg.). These changes are what would be expected from reduced fire frequency. Stine et al. (2014) presented photographs documenting similar changes in the Okanogan-Wenatchee National Forest in Oregon during 1934 to 2010 .

Addington et al. (2018) conducted a detailed study of ponderosa pine forests of the Colorado Front Range using historical photography. They concluded that historical fire frequency was likely much higher before the mid- to late1800s. A comparison of photographs from 1896, 1899, and 1905 to recent photography (past 20 years) showed ubiquitous and dramatic increases in tree density. Extensive historical photographs supporting these conclusions have been compiled (Veblen and Lorenz 1991). This trend was spatially 
extensive and agreed with trends in the Southwest, according to the authors (and see Brown and Wu 2005). They noted that, in addition to fewer fires, a history of extensive grazing since settlement would have favored pine establishment by reducing grass competition with pine seedlings. The extent to which upper ecotone expansion has resulted from grazing is unclear because no references cited here documented grazing in their study areas. However, for grazing to have kept alpine meadows free of trees, grazing would have had to have had the opposite effect as at lower elevations and to have been ubiquitous. Lack of documentation makes this question impossible to resolve at this time.

Work by Stephens et al. (2015) extended evidence for densification of ponderosa pine and mixed conifer forest into the southern Sierra Nevada of California. In their study, they combined historical photography with inventories conducted in 1911. They found canopy cover to have increased from $25 \%$ to $49 \%$ in mixed conifer stands and from $12 \%$ to $49 \%$ in ponderosa pine stands. They attributed this change to altered fire regimes. Other work extends the areas where forest has become denser and less fire tolerant to Grand Canyon National Park (Mast and Wolf 2004); the San Juan Mountains of Colorado (Elliott and Baker 2004), where aspen has been infilling conifer stands since 1900 but more so recently; the San Francisco Peaks in Arizona (Cocke et al. 2005), especially in lower elevation zones; ponderosa and mixed conifer types in south-central Oregon (Hagmann et al. 2013); and the Medicine Bow Mountains of Wyoming (Andersen and Baker 2005), where forest openings on survey transects have shrunk $7.3 \%$ in the past 110 years. In addition, increased density has been documented in New Mexico (Margolis and Malevich 2016; Swetnam et al. 2016) and Arizona (O'Connor et al. 2014).

Based on the assumption that tree seedling density represents more recent climate responses than does adult density, Monleon and Lintz (2015) evaluated 46 species across California, Oregon, and Washington. More species had higher elevation and/or more northerly seedling distributions compared to adult distributions. Over all species, mean seedling distribution peaks (not range boundaries) were $26.58 \mathrm{~m}$ higher and $11.22 \mathrm{~km}$ farther north than adult trees. Note, however, that the recent drought in the Southwest could be partially responsible for this trend if dryness has inhibited seedling establishment more in the South and at low elevations. Whether this will continue is an open question.

Hanberry and Hansen (2015) evaluated areal coverage of species in latitudinal bands across the conterminous US based on forest inventory data. Trees were counted if $>12.7$ $\mathrm{cm} \mathrm{dbh}$ and the survey interval was approximately 28 years. Of strictly western species, Englemann spruce, Rocky Mountain juniper, and white spruce (Picea glauca (Moench) Voss) had statistically significant areal expansion of adult trees in their northernmost band within the US and non-significant southern band changes. Limber pine expanded in both directions. Subalpine fir expanded to the south. Note that four of these five species are high elevation types. No species had a net significant range shrinkage. Fourteen species with adequate data (not too rare) showed no significant change.

In contrast to the extensive literature showing forest expansion and densification across the drier portions of the West and at upper elevations, there is evidence that recent regeneration following severe fires has been deficient in Arizona (Roccaforte et al. 2012), Colorado (Chambers et al. 2016; Rother and Veblen 2016), New Mexico (Savage et al. 2013), Oregon (Dodson and Root 2013), and across the West (Stevens-Rumann et al. 2018). This is a result of the recent drought which has limited regeneration success, plus the total kill of adult trees in many areas which makes seed dispersal a limiting factor (see Roccaforte et al. 2012; Chambers et al. 2016; Rother and Veblen 2016). A cessation of the recent drought would enhance recovery, but dispersal limitation will remain an issue where large fires have removed all nearby seed sources. The extent to which trees are replanted will influence forest recovery. In the absence of seed sources or replanting, a likely pathway following fire is persistent shrubfields (Savage et al. 2013) or grasslands.

\section{Mortality events}

Mass mortality may be a sign that forest growth has been negatively affected. Aspen is one species that has exhibited extensive mortality in some locations in the West. A severe drought during 2002-2008 caused extensive trembling aspen mortality in Colorado (Worrall et al. 2008, 2010; Anderegg et al. 2013). A complicating factor, however, is that aspen is a short-lived, disturbance-dependent species and thus older stands will be inherently more subject to mortality events. In an area of Colorado, for example, Binkley et al. (2014) found that most aspen stands at 100 to 140 years-old are approaching the maximum age for the species, with consequent dieback likely. The advanced age of these stands may result from low fire frequency in the $20^{\text {th }}$ century that reduced stand establishment events. Worrall et al. (2013) concluded that across its range, aspen dieback was typically preceded by drought, tended to occur on marginal (i.e., drier) sites, and was exacerbated by insect and pathogen attack. While aspen appears to be sensitive to drought, there is also evidence that sucker regeneration is common in the understory of stands experiencing dieback (Frey et al. 2004). A key factor in aspen decline may be the influence of ungulate browsing on aspen regeneration. Beschta et al. (2016) found that historical data on exclosures in Yellowstone National Park and recent fluctuations in Rocky Mountain elk (Cervus elaphus L.) populations both point to herbivory as a limiting factor for aspen sucker success. In the northern part of the park, where elk abundance had declined, aspen stands were recovering. The following thus seems plausible: all aspen, but particularly old aspen stands and those on dry sites, are prone to dieback, and when there is excessive herbivory, are unable to recover. Aspen in some cases may also be lost due to successional processes (Bretfeld et al. 2016).

Millar et al. (2007) documented a mortality event in lower-elevation, young limber pine stands in the eastern Sierra Nevada range during 1985 to 1995 . This was a period of high temperature and persistent drought in the region, according to their data. They noted that thinning caused by the drought led to increased resilience and no mortality during the subsequent 1999-2004 drought. Recent droughtcaused mortality is also evident in subalpine forests of the Colorado Front Range (Smith et al. 2015). Allen and Breshears (1998), for a study area in northern New Mexico, documented that drought killed ponderosa pine and caused a several-kilometer shift upslope in the ecotone with piñon- 
juniper woodland that persisted for more than 40 years as of their study date. Such shifts have not yet been documented to be widespread.

In subalpine zones of eastern California, mortality of whitebark pine (P. albicaulis Engelm.) was documented by Millar et al. (2012) to have occurred during the 2007-2010 drought. Stands with high mortality tended to have high density and to occur on lower elevations (mean $2993 \mathrm{~m}$ ), on northerly aspects, and to have drier and warmer conditions relative to the typical condition for this species. Excess density may predispose stands to drought-caused mortality (Young et al. 2017).

Regional droughts can be extensive and have large impacts. Droughts have been ongoing in California (Guarín and Taylor 2005; Griffin and Anchukaitis 2014; Belmecheri et al. 2016; Robeson 2015) and the American West (Weiss et al. 2009) for the past decade or so. Oscillations in Pacific storm tracks (Dannenberg and Wise 2017) can have a large impact on western precipitation patterns. Precipitation in California (Kirby et al. 2014) and the West generally (McCabe and Dettinger 2002) up into western Canada (Cayan et al. 1998; Steinman et al. 2014) are linked to Pacific Ocean cycles (Kadonaga et al. 1999; Gray et al. 2003). Mote et al. (2018) documented a downward trend in reconstructed western April $1^{\text {st }}$ snowpack, and Belmecheri et al. (2016) showed that the 2015 Sierra Nevada snowpack was anomalously low compared to the past 500 years. However, in this same 500-year record, the past 100 or 50 years seem similar to the overall record. Considered as a multi-year event, the 2012-2014 or 2012-2015 periods were highly unusual (Griffin and Anchukaitis 2014; Robeson 2015) in California. As a result of this drought, tree mortality in California rose dramatically (Van Mantgem et al. 2009; Berner et al. 2017, 2019; Young et al. 2017). Discrete mortality events since 1984 have been better documented in Arizona and New Mexico due to fire and insect infestations (Williams et al. 2010). Hember et al. (2017) also documented small increases in drought-induced tree mortality across the Rocky Mountain and Cascade Ranges. Cohen et al. (2016) found a recent increase in western disturbance events.

Even on sites experiencing drought, however, tree mortality rates should be interpreted cautiously. Thorpe and Daniels (2012) noted that self-thinning and succession accounted for most of the mortality trends in their study in Alberta, Canada. Millar et al. (2012) and Young et al. (2017) showed that stands with higher density evinced higher mortality during droughts. The long-term trend toward higher density over the past century could thus be increasing western mortality during drought periods. In regions such as the Southwest subject to cyclical climate, a process of over-shoot and dieback can occur (Jump et al. 2017). During wetter decades and following fire suppression, trees can become established and grow faster, increasing forest density. When a dry period recurs, there is more biomass than can be supported and dieback or pathogen mortality will occur. Dieback in such cases will be more dramatic than in a dry, but stable, climate regime.

Mortality caused by insects and disease (pathogens) can be dramatic (Berner et al. 2017, 2019) but is difficult to interpret. Regional differences in pathogen-caused mortality, especially bark beetles, have been documented (Reilly and
Spies 2016; Berner et al. 2017, 2019). Due to lack of historical data, it is difficult to tell if pathogen incidence is increasing. There are known invasive pests which are causing mortality, but the recent droughts make separating this effect from total mortality problematic.

\section{Growth trend reconstructions}

Historical reconstructions based on permanent plots and or tree-ring records have the potential to provide estimates of changes in forest growth rates, although changes in stand age and density need to be considered. Stand-level biomass for even-aged (e.g., after fire) stands increases over time with a maximum yearly increment shortly after crown closure and a decline to minimal accumulation (i.e., steady state) for very old stands (e.g., Kashian et al. 2013). This age effect needs to be considered for growth trend reconstruction. Given the large historical increases in stand density documented in prior section, which could reduce individual tree growth due to water limitation (Biondi 1999) and crowding, care must also be taken that density over time is comparable in growth studies.

Several studies appear to have detected a $\mathrm{CO}_{2}$ growth response. Soulé and Knapp (2006) evaluated ponderosa pine growth on eight minimally disturbed sites across central Oregon and northern California. They matched time periods in terms of moisture stress. They found a growth enhancement at all sites after 1950 and significantly at most sites, which they attributed to $\mathrm{CO}_{2}$ fertilization which increased drought tolerance. Growth was most enhanced during dry years and on the driest sites. They did not quantify the growth response per se. Gedalof and Berg (2010) also found some evidence for $\mathrm{CO}_{2}$ fertilization effects. Using the global tree-ring database, they modeled tree-ring response to climate and examined residuals for a $\mathrm{CO}_{2}$ signal. They found that $20 \%$ of sites globally exhibited a positive response to rising $\mathrm{CO}_{2}$. They found that Douglas-fir and ponderosa pine appeared to be responding to $\mathrm{CO}_{2}$ but at the bounds of detectability. Reed et al. (2018) evaluated lodgepole pine growth in west-central Montana and into Idaho for the period 1950-2015. They found stem biomass growth to be enhanced by rising intrinsic water use efficiency (iWUE) caused by rising $\mathrm{CO}_{2}$ on dry sites. On wetter sites, rising iWUE was not adequate to compensate for falling snowpack, causing a slight growth decline.

Graumlich et al. (1989) found a large growth enhancement based on four sites in western Washington Douglas-firhemlock forests. Using reconstructions for stands without any obvious mortality (evident due to the slow decay of large trees in that locality), they inferred a regional increase in growth of $60 \%$ over the period 1880 to 1979 . They ruled out a significant $\mathrm{CO}_{2}$ effect and attributed most of the enhancement to warming, with precipitation having mainly shortterm effects. This study is now 40 years old, so an update would be informative.

In contrast to Graumlich et al. (1989), Lee et al. (2016), also for Douglas-fir, found a $20^{\text {th }}$ Century (to 2010) pattern of fluctuations due to the Pacific Decadal Oscillation and other cycles and periodic growth reductions due to Swiss needle cast (Phaeocryptopus gaeumannii (T. Rhode) Petrak) infection. The authors did attempt to reduce effects of tree ring detrending methods on suppression of long-term growth trends. They found no recent trend for three wet coastal sites, 
a decline at low elevation interior dry sites since 1980 or 1990, and an increase since 1990 at high elevation sites, the latter two being responses to warming.

Salzer et al. (2009) found that bristlecone pine growth in the second half of the $20^{\text {th }}$ century was unprecedented in the past 3700 years, but only in a narrow $(\sim 150 \mathrm{~m})$ band at treeline, regardless of elevation. Similarly, Hughes and Funkhouser (2003) found that bristlecone pine and foxtail pine (P. balfouriana Balf.) showed continuously increasing growth since the mid-1800s at upper ecotone sites but not lower ecotone sites in the Great Basin. The growth surge was positively associated with temperature. Note that these growth increases are very spatially restricted and match the ecotone expansions found by Millar et al. (2015) and Smithers et al. (2018). In contrast, Perkins and Swetnam (1996) found no unusual growth response for high elevation whitebark pine in the Sawtooth-Salmon River region of Idaho. Growth appeared to be dependent on snowpack depth. A small-scale study of foxtail pine near alpine treeline in Sequoia National Park, California (Bunn et al.2005) found four wet sites to have an increasing growth trend since the mid-1800s and four drier sites to show no trend over the same period.

McIntyre et al. (2015) used US Forest Service forest inventory data from surveys in the 1930s vs. the 2000s to study changes in California forests. Over this time period, they found a $30 \%$ increase in tree density, fewer large trees, and a $19 \%$ reduction in basal area (an indicator of biomass). However, Roesch and Van Deusen (2010) showed that a change in survey methods across the two time periods had the effect of making large trees less observable. In addition, forest harvesting since the 1930s could have produced these same changes in structure by creating a younger forest.

Woolley et al. (2015) evaluated growth trends at eight sites in western Oregon. Annual biomass production (area basis) was estimated on permanent plots based on tree diameter increments and allometric equations over intervals from 12 to 32 years-long. Although age correction was not done, the relatively short interval between samples and the long periods during which these forests are highly productive make this only a minor issue. Of these sites, an old-growth site showed a decline in total annual bole biomass production, a mature site an increase, and the rest no trend. Individual tree responses were more coherent in younger stands, probably due to weather effects.

Tree-ring records from across the West were used by McKenzie et al. (2001) to evaluate growth trends during 1880 to 1980 . They found a periodic signal in the Southwest, as discussed previously. They found large positive growth trends at a subset of high elevation and high latitude sites and no declines. However, Nehrbass-Ahles et al. (2014) concluded that the data selection method used by McKenzie et al. (2001) was likely to yield a positive bias to growth trends. It is likely that despite this bias, the study does provide some evidence for stable to increasing growth rates. It might be useful to update these 40-year-old data.

Del Grosso et al. (2008) simulated global net primary productivity (NPP) trends over the period 1901-2000, with fixed $\mathrm{CO}_{2}$. They found that total NPP (TNPP) increased from $12 \%$ to $50 \%$ over virtually all of Canada and the central and western US (but not the US Rockies region from New Mexico up through Colorado) over the 100 years, and 13\% globally. Results from simulations such as these depend critically on reliability of interpolated older weather station records, realism of the growth models used, and whether $\mathrm{CO}_{2}$ enhancement is included. Because $\mathrm{CO}_{2}$ effects were not simulated, this study may be underestimating a growth response.

Case and Peterson (2007) constructed growth factor models for lodgepole pine in the North Cascades National Park based on detrended ring width series for the period 1930 to 2000 . While the lower elevation sites (more limited by precipitation) showed an upward trend for 1945-1985 and a dip in the 1990s, there was no obvious long-term trend. Higher elevation sites (more limited by temperature) fluctuated around the mean over the entire 70 years. Because detrending may have removed any signal of slowly rising $\mathrm{CO}_{2}$, small upward growth responses might have been concealed in this analysis.

\section{Discussion}

Some changes in western forests (elevational ecotones, growth rates) have likely resulted from more than one factor (Table 1). Forest aging, increased density, and drought can all affect mortality rates and growth rates. Results from the reviewed studies must therefore be synthesized carefully. For example, increase in density of dry forests across the West seems to be clearly the result of a change in fire regimes (Brown et al. 2015; Millar et al. 2015; Stephens et al. 2015; Addington et al. 2018; Klimaszewski-Patterson et al. 2018). Because of the dry climate and slow growth of trees, it has taken a long time for this change to occur. The expansion of forest at dry ecotones in the West is similar to global trends (Stevens et al. 2016; Nelson and Reams 2017) and may be the combined result of reduced fire incidence, grazing, and $\mathrm{CO}_{2}$ fertilization, which favors trees over herbaceous species (Loehle et al. 2016), with some contribution from rising precipitation in some areas (Bishop et al. 2018). The interactions between forest density, fire, growth rates, drought, and forest extent (Fig. 2) are complex and play out over many decades.

Historically, treelines across the West have fluctuated above and below the current elevation due to changes in both precipitation and temperature (Rochefort et al. 1994). Dates of treeline changes (Rochefort et al. 1994) are not obviously spatially synchronous over the past 10000 years across the West. This can be explained by the various limiting factors at particular sites. For sites where wind scours the surface, killing plants and leading to local, large snow drifts (e.g., in ribbon forest, Billings 1969), a change in prevailing winter winds could alter the treeline in complex ways. Decreased snowpack could allow wet meadows to be invaded while making drier meadows less suitable. Very large alpine fires could create persistent conditions unfavorable to seedlings or require a long recovery (Billings 1969; Shankman and Daly 1988), thus causing a locally lowered treeline for long periods unrelated to climate. Sites with very thin soils or where snow is all blown away might require a much greater change in climate before trees could become established. These same factors lead us to expect that current treeline rise in the West should not follow a warming climate in a uniform way but should rather be both locally variable and intermittent in time (not continuous). This is what appears to be the case. Thus, while studies agree that treeline invasions or extensions began after the 1850s, the decade and pattern differs from 
Table 1. Summary of Findings

\begin{tabular}{|c|c|c|c|c|}
\hline Reference & Region & Period & Method & Finding \\
\hline Multiple $^{1}$ & Alpine & Various to $1700 \mathrm{~s}$ & $\begin{array}{l}\text { Historical photography, } \\
\text { tree ageing }\end{array}$ & Alpine meadow colonization \\
\hline Multiple $^{2}$ & $\begin{array}{l}\text { Ponderosa pine, mixed } \\
\text { conifer across the West }\end{array}$ & From 1860s & $\begin{array}{l}\text { Historical photography, } \\
\text { inventory data }\end{array}$ & Increased density \\
\hline $\begin{array}{l}\text { Monleon and } \\
\text { Lintz } 2015\end{array}$ & CA, OR, WA & Recent & $\begin{array}{l}\text { Seedlings vs. adult } \\
\text { distributions }\end{array}$ & $\begin{array}{l}\text { Upward and northward shifts in } \\
\text { peak abundance }\end{array}$ \\
\hline $\begin{array}{l}\text { Hanberry and } \\
\text { Hansen } 2015\end{array}$ & Conterminous US & $\begin{array}{l}\text { Recent } 28 \text { year survey } \\
\text { interval }\end{array}$ & Tree geographic change & $\begin{array}{l}\text { Four spp. elevational expansion, } \\
2 \text { spp. to south, } 14 \text { spp. no change }\end{array}$ \\
\hline Multiple $^{3}$ & Across the West & Recent decades & Regeneration surveys & Inadequate regeneration \\
\hline Multiple $^{4}$ & Across drier West & Recent decades & Inventory data, surveys & Tree mortality events \\
\hline $\begin{array}{l}\text { Soulé and } \\
\text { Knapp } 2006\end{array}$ & $\begin{array}{l}\text { Central OR, northern CA } \\
\text { ponderosa pine forest }\end{array}$ & $20^{\text {th }}$ century & Tree-ring data & Enhanced growth post-1950 dry sites \\
\hline $\begin{array}{l}\text { Gedalof and } \\
\text { Berg } 2010\end{array}$ & Across the West & $20^{\text {th }}$ century & Tree-ring data & $\mathrm{CO}_{2}$ fertilization effect \\
\hline $\begin{array}{l}\text { Graumlich et al. } \\
1989\end{array}$ & Western WA moist forest & $1880-1979$ & Stand growth & $60 \%$ increase \\
\hline $\begin{array}{l}\text { Salzer et al. } \\
\text { 2009; Hughes and } \\
\text { Funkhouser } 2003\end{array}$ & CA, Great Basin & $3700 \mathrm{yr}$ & Tree rings & $\begin{array}{l}\text { Pine increased growth in narrow } \\
\text { elevation bands }\end{array}$ \\
\hline $\begin{array}{l}\text { Case and } \\
\text { Peterson } 2007\end{array}$ & $\begin{array}{l}\text { North Cascades National } \\
\text { Park, WA }\end{array}$ & $1930-2000$ & Tree rings & $\begin{array}{l}\text { No net trend high or low } \\
\text { elevation }\end{array}$ \\
\hline Lee et al. 2016 & OR & $1890-2010$ & Tree rings & Mixed recent responses \\
\hline $\begin{array}{l}\text { Perkins and } \\
\text { Swetnam } 1996\end{array}$ & ID & Historical & Tree rings & No change \\
\hline Bunn et al. 2005 & CA & Mid-1800s to present & Tree rings & $\begin{array}{l}\text { Increased growth at } 4 \text { wet sites, no } \\
\text { trend at } 4 \text { dry sites }\end{array}$ \\
\hline $\begin{array}{l}\text { McIntyre et al. } \\
2015\end{array}$ & $\mathrm{CA}$ & 1930s-2000s & Inventory data & $\begin{array}{l}\text { Decreased basal area but methods } \\
\text { may have caused artifact }\end{array}$ \\
\hline Reed et al. 2018 & West-central ID, to MT & $1950-2015$ & $\begin{array}{l}\text { Tree-ring and isotope data, } \\
\text { lodgepole pine }\end{array}$ & $\begin{array}{l}\text { Increased growth on dry sites, } \\
\text { reduced growth on wet sites }\end{array}$ \\
\hline $\begin{array}{l}\text { Woolley et al. } \\
2015\end{array}$ & Western OR & $12-32$ yr remeasure & Stand growth & No net trend \\
\hline $\begin{array}{l}\text { McKenzie et al. } \\
2001\end{array}$ & Across the West & $1880-1980$ & Tree-ring records & $\begin{array}{l}\text { Large positive trends at some high } \\
\text { altitude and high latitude sites, no } \\
\text { declines }\end{array}$ \\
\hline $\begin{array}{l}\text { Del Grosso et al. } \\
2008\end{array}$ & West & $1901-2000$ & Modeled NPP & $\begin{array}{l}\text { Increase in West except Rockies } \\
\text { region }\end{array}$ \\
\hline
\end{tabular}

${ }^{1}$ Alftine et al. 2003; Bekker 2005; Billings 1969; Butler and DeChano 2001; Butler et al. 1994; Coop and Givnish 2007; Daley and Shankman 1985; DeBenedetti and Parsons 1979; Dunwiddie 1977; Dyer and Moffett 1999; Franklin et al. 1971; Halpern et al. 2010; Haugo and Halpern 2010; Helms 1987; Jakubos and Romme 1993; Klasner and Fegre 2002; Millar et al. 2004, 2015; Moir et al. 1999; Moore and Huffman 2004; Rice et al. 2012; Shankman and Daly 1988; Smithers et al. 2017; Taylor 1990, 1995; Vale 1978, 1981 ${ }^{2}$ Addington et al. 2018; Andersen and Baker 2005; Brown et al. 2015; Brown and Wu 2005; Cocke et al. 2005; Elliott and Baker 2004; Hagmann et al. 2013; Margolis and Malevich 2016; Mast and Wolf 2004; O'Connor et al. 2014; Stephens et al. 2015; Stine et al. 2014; Swetnam et al. 2016; Veblen and Lorenz 1991

${ }^{3}$ Beschta et al. 2016; Chambers et al. 2016; Dodson and Root 2013; Frey et al. 2004; Roccaforte et al. 2012; Rother and Veblen 2016; Savage et al. 2013; Stevens-Rumann et al. 2018

${ }^{4}$ Allen and Breshears 1998; Anderegg et al. 2013; Binkley et al. 2014; DeRose et al. 2012; Hember et al. 2017; Millar et al. 2007, 2012; Smith et al. 2015; van Mantgem et al. 2009; Williams et al. 2010; Worrall et al. 2008, 2010, 2013 
Fire Suppression

Increased Density

Reduced Growth

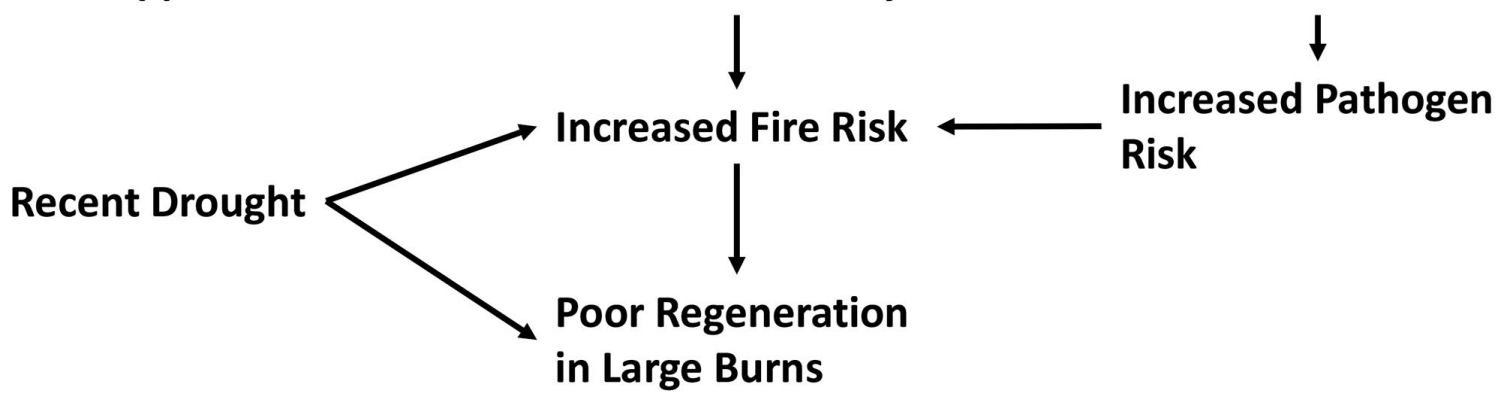

Fig. 2 Causal interactions of fire, drought, and density on forest condition

place to place, in some cases by a century. Some sites show continuous and some episodic (e.g., Helms 1987) invasion. A general amelioration due to warming is evident but a climate signal cannot always be teased out of the response at any particular site. In fact, multiple studies have failed to find climate correlates of invasion success (e.g., Jakubos and Romme 1993; Halpern et al. 2010; Rice et al. 2012).

Increases in tree mortality documented by multiple authors may not necessarily presage large-scale forest loss. For aspen mortality, stand aging and drought were noted above to be proximate factors, with failure to regenerate being perhaps due to ungulate grazing. Drought diebacks have been documented in the Southwest (Allen and Breshears 1998; Millar et al. 2007; Williams et al. 2010) and increased rates of mortality have also been documented by Smith et al. (2015), van Mantgem et al. (2009), Cohen et al. (2016) and Hember et al. (2017). The already-noted historical increase in stand densities in drier forests could have led to an overshoot condition (per Jump et al. 2017) in which too much biomass exists for trees to be tolerant of drought (Voelker et al.2019). This would cause excess mortality in the event of drought. Increased density in dry forests could help convert a low-intensity fire to a high-intensity fire by making fuels more continuous. In a drought, higher recent densities could also lead to more likelihood of insect or disease attack if more trees are stressed. Vankat (2017) documented this type of dynamic in pinyon-juniper (P. edulis Engel., Juniperus scopulorum) woodland on the South Rim of Grand Canyon National Park, Arizona. In the core zone of this type, periodic droughts causing mortality followed by recovery were observed during 1935-2011. In contrast, at the ecotone with ponderosa pine, the forest was much more stable.

Drought and fire-caused dieback at dry ecotones is what is predicted to result from warming. The open question at this time is whether recent forest losses due to fire and drought, especially in California, will be permanent. The many decades required for forest to reoccupy burned areas (StevensRumann et al. 2018), especially if large, make determination of permanence or not of dry margin losses a slow process.
This is especially true during an ongoing drought, when tree establishment is likely to be low. In some cases, large burns can convert forest to shrub fields (e.g., Guiterman et al. 2018), which may make tree establishment difficult or promote further fires (Fig. 2).

One test of whether tree ranges are shrinking is provided by Hanberry and Hansen (2015). In their 28-year resurvey of most of the abundant western tree species, none were found to have significant areal extent shrinkage (number of plots in which they were found) and five, mostly alpine species, had expanded. Resolution of their data did not allow for small changes to be detected. By this measure, whatever diebacks or fire losses occurred during their study period do not appear to be affecting tree spatial extents in the West at scales that are detectable.

Direct evidence of changes in productivity per se are sparse. A large increase since 1901 in productivity for the US, including the Pacific Northwest, was inferred by Del Grosso et al. (2008) by simulation, though not for the Rockies region. Graumlich et al. (1989) found a 60\% increase in plot-scale NPP during 1880 to 1979 in Washington. This study, however, had end dates 40 years ago and thus cannot be considered indicative of current trends. A large growth spurt in bristlecone pine (Salzer et al. 2009) is very local. There is some evidence for modestly increased growth of trees due to $\mathrm{CO}_{2}$ fertilization (e.g., Soulé and Knapp 2006; Gedalof and Berg 2010; Reed et al. 2018). As it is likely, based on both experimental work and models of photosynthesis (see Loehle et al. 2016) that rising $\mathrm{CO}_{2}$ should increase tree growth and drought tolerance, it would be beneficial if this aspect were studied more thoroughly. While there is some indication of increased tree growth at higher elevations (McKenzie et al. 2001; Bunn et al. 2005; Salzer et al. 2009; Lee et al. 2016; Millar et al. 2015; Monleon and Lintz 2015), this trend may soon be countered by reduced growth due to declining snowpack (Mote et al. 2018; but see Siler et al. 2018). In the inland Northwest, various authors found slight growth declines (Lee et al. 2016; Reed et al. 2018) and mostly stable growth (Case and Peterson 2007; Woolley et al. 2015). Between these tem- 
perature extremes (hot and dry Southwest and subalpine zones), it is difficult to make any firm statements about growth trends from available data. The lack of clear growth trends is consistent with the lack of effective moisture trends over the past 70 years across the region (Greve et al. 2014). The ambiguity of existing growth studies means that increased tree growth cannot be directly invoked to explain elevational expansion in this region. Seedling establishment limitations due to snowpack may be the more parsimonious explanation (Franklin et al. 1971). Further studies of historical growth trends would be useful, with the effect of stand density changes being carefully considered.

An important open question is whether drought, particularly in the Southwest, will continue. For example, the California Department of Water Resources reported the seasonal (October 1, 2018 - February 28, 2019) precipitation to be $130 \%$ of average statewide, perhaps signaling an end to the drought. While some long-term climate patterns appear to exist (Kadonaga et al. 1999; Gray et al. 2003; Woodhouse 2003) that may have predictable impacts on tree growth (e.g., Gray et al. 2003; Lee et al. 2016), it is not yet possible to make forecasts based on these patterns. Precipitation trends will particularly affect regeneration after fire. Fire per se, however, will probably continue to be an issue even if the recent drought ends due to the higher than historical fuel loads and more spatially continuous fuel structures. Model-based forecasts of climate change effects (Loehle 2018) indicate both increased growth in many regions plus increased fire risk. Research needs include an assessment of the extent and rate of upslope forest movement, more studies of forest growth trends, and follow-up of regeneration in recently burned areas.

Forests provide a valuable carbon storage service. The documented increased density over the past 100 years in the West suggests a large increase in $\mathrm{C}$ storage over this period. This is particularly true because much of the region is not managed for timber. However, the increase in fire acreage since the 1980s, especially in California, calls into question the permanence of these gains. It may be necessary to consider whether lower density in fire-prone zones might help protect against forest loss. Careful analysis of this question would be required to determine an answer.

\section{Acknowledgement}

This research was supported by The National Council for Air and Stream Improvement, Inc. Thanks to D. A. Miller and T.B. Wigley for helpful suggestions. Map provided by Steve Prisley. The author asserts no conflicts of interest.

\section{References}

Addington, R.N. et al. 2018. Principles and practices for the restoration of ponderosa pine and dry mixed-conifer forests of the Colorado Front Range. USDA For. Serv. Gen. Tech. Rep. RMRSGTR-373.

Alftine, K.J., G.P. Malanson and D.B. Fagre. 2003. Feedbackdriven response to multidecadal climatic variability at an alpine treeline. Phys. Geogr. 24(6): 520-535. doi:10.2747/0272-3646.24.6.520.

Allen, C.D. and D.D. Breshears. 1998. Drought-induced shift of a forest-woodland ecotone: Rapid landscape response to climate variation. Proc. Natl. Acad. Sci. USA 95(25): 14839-14842.
Allen, C.D., D.D. Breshears and N.G. McDowell. 2015. On underestimation of global vulnerability to tree mortality and forest die-off from hotter drought in the Anthropocene. Ecosphere 6(8): 129. doi:10.1890/es15-00203.1.

Allen, C.D. et al. 2010. A global overview of drought and heatinduced tree mortality reveals emerging climate change risks for forests. For. Ecol. Manag. 259(4): 660-684. doi:10.1016/j.foreco. 2009.09.001

Anderegg, L.D., W.R.L. Anderegg, J. Abatzoglou, A.M. Hausladenand J.A. Berry. 2013. Drought characteristics' role in widespread aspen forest mortality across Colorado, USA. Glob. Change Biol. 19(5): 1526-1537. doi:10.1111/gcb.12146.

Anderegg, W.R.L., A. Flint, C.-Y. Huang, L. Flint, J.A. Berry, F.W. Davis, J.S. Sperry and C.B. Field. 2015. Tree mortality predicted from drought-induced vascular damage. Nat. Geosci. 8(5): 367-371. doi:10.1038/ngeo2400.

Andersen, M.D. and W.L. Baker. 2005. Reconstructing landscapescale tree invasion using survey notes in the Medicine Bow Mountains, Wyoming, USA. Landsc. Ecol. 21(2): 43-258. doi:10.1007/ s10980-005-1938-3.

Bekker, M.F. 2005. Positive feedback between tree establishment and patterns of subalpine forest advancement, Glacier National Park, Montana, USA. Arct. Antarct, Alp. Res. 37(1): 97-107. doi:10.1657/1523-0430(2005)037[0097:pfbtea]2.0.co;2.

Belmecheri, S., F. Babst, E.R. Wahl, D.W. Stahle and V. Trouet, V. 2016. Multi-century evaluation of Sierra Nevada snowpack. Nat. Clim. Change 6(1): 2-3. doi:10.1038/nclimate2809.

Berner, L.T., B.E. Law, A.J.H. Meddens and J.A. Hicke. 2017. Tree mortality from fires, bark beetles, and timber harvest during a hot and dry decade in the western United States (2003-2012). Environ. Res. Lett. 12(6): 065005. doi:10.1088/1748-9326/aa6f94.

Berner, L.T., B.E. Law, A.J.H. Meddens and J.A. Hicke. 2019. Corrigendum: Tree mortality from fires, bark beetles, and timber harvest during a hot and dry decade in the western United States (2003-2012) (2017 Environ. Res. Lett. 12(6): 065005). Environ. Res. Lett. 14(5): 059501. doi:10.1088/1748-9326/ab1690.

Beschta, R.L., L.E. Painter, T. Levi and W.J. Ripple. 2016. Longterm aspen dynamics, trophic cascades, and climate in northern Yellowstone National Park. Can. J. For. Res. 46(4): 548-556. doi:10.1139/cjfr-2015-0301.

Billings, W.D. 1969. Vegetational pattern near alpine timberline as affected by fire-snowdrift interactions. Veg. 19(1-6): 192-207. doi:10.1007/bf00259010.

Binkley, D., A. Alsanousi and W.H. Romme. 2014. Age structure of aspen forests on the Uncompahgre Plateau, Colorado. Can. J. For. Res. 44(7): 836-841. doi:10.1139/cjfr-2014-0017.

Biondi, F. 1999. Comparing tree-ring chronologies and repeated timber inventories as forest monitoring tools. Ecol. Appl. 9(1): 216227. doi:10.1890/1051-0761(1999)009[0216:ctrcar]2.0.co;2.

Bishop, D.A., A.P. Williams, R. Seager, A.M. Fiore, B.I. Cook, J.S. Mankin, D. Singh, J.E. Smerdon and M.P. Rao. 2019. Investigating the causes of increased twentieth-century fall precipitation over the southeastern United States. J. Clim. 32(2): 575-590. doi:10.1175/ jcli-d-18-0244.1.

Boisvenue, C. and S.W. Running. 2006. Impacts of climate change on natural forest productivity - evidence since the middle of the $20^{\text {th }}$ century. Glob. Change Biol. 12(5): 862-882. doi:10.1111/j.13652486.2006.01134.x.

Bretfeld, M., S.B. Franklin and R.K. Peet. 2016. A multiple-scale assessment of long-term aspen persistence and elevational range shifts in the Colorado Front Range. Ecol. Monogr. 86(2): 244-260. doi:10.1890/15-1195.1.

Brown, P.M. and R. Wu. 2005. Climate and disturbance forcing of episodic tree recruitment in a southwestern ponderosa pine landscape. Ecol. 86(11): 3030-3038. doi:10.1890/05-0034. 
Brown, P.M., M.A. Battaglia, P.J. Fornwalt, B. Gannon, L.S. Huckaby, C. Julian and A.S. Cheng. 2015. Historical (1860) forest structure in ponderosa pine forests of the northern Front Range, Colorado. Can. J. For. Res. 45(11): 1462-1473. doi:10.1890/05-0034. Bunn, A.G., L.A. Waggoner and L.J. Graumlich. 2005. Topographic mediation of growth in high elevation foxtail pine (Pinus balfouriana Grev. et Balf.) forests in the Sierra Nevada, USA. Glob. Ecol. Biogeogr. 14(2): 103-114. doi:10.1111/j.1466-822x.2005.00141.x. Burns, R.M. and B.H. Honkala. 1990. Silvics of North America. Agriculture Handbook 654 (Vols. 1, 2). USDA, Washington, DC. Butler, D.R. and L.M. DeChano. 2001. Environmental change in Glacier National Park, Montana: An assessment through repeat photography from fire lookouts. Phys. Geogr. 22(4): 291-304. doi:10.1080/02723646.2001.10642744.

Butler, D.R., G.P. Malanson and D.M. Cairns. 1994. Stability of alpine treeline in Glacier National Park, Montana, USA. Phytocoen. 22(4): 485-500.

Campbell, J.E., J.A. Berry, U. Seibt, S.J. Smith, S.A. Montzka, T. Launois, S. Belviso, L. Bopp and M. Laine. 2017. Large historical growth in global terrestrial gross primary production. Nature 544(7648): 84-87. doi:10.1038/nature22030.

Case, M.J. and D.L. Peterson. 2007. Growth-climate relations of lodgepole pine in the North Cascades National Park, Washington. Northwest Sci. 81(1): 62-76. doi:10.3955/0029-344x-81.1.62.

Cayan, D.R., M.D. Dettinger, H.F. Diaz and N.E. Graham. 1998. Decadal variability of precipitation over western North America. J. Clim. 11(12): 3148-3166. doi:10.1175/1520-0442(1998)011<3148: dvopow $>2.0 . \mathrm{co} ; 2$.

Chambers, M.E., P.J. Fornwalt, S.L. Malone and M.A. Battaglia. 2016. Patterns of conifer regeneration following high severity wildfire in ponderosa pine-dominated forests of the Colorado Front Range. For. Ecol. Manag. 378: 57-67. doi:10.1016/j.foreco. 2016.07.001.

Cocke, A.E., P.Z. Fulé and J.E. Crouse. 2005. Forest change on a steep mountain gradient after extended fire exclusion: San Francisco Peaks, Arizona, USA. J. Appl. Ecol. 42(5): 814-823. doi:10.1111/ j.1365-2664.2005.01077.x.

Cohen W.B., Z. Yang, S.V. Stehman, T.A. Schroeder, D.M. Bell, J.G. Masek, C. Huang and G.W. Meigs. 2016. Forest disturbance across the conterminous United States from 1985-2012: The emerging dominance of forest decline. For. Ecol. Manag. 360: 242-252. doi:10.1016/j.foreco.2015.10.042.

Coop, J.D. and T.J. Givnish. 2007. Spatial and temporal patterns of recent forest encroachment in montane grasslands of the Valles Calera, New Mexico, USA. J Biogeogr. 34(5): 914-927. doi:10.1111/j.1365-2699.2006.01660.x.

Daly, C. and D. Shankman. 1985. Seedling establishment by conifers above tree limit on Niwot Ridge, Front Range, Colorado, USA. Arct. Alp. Res. 17(4): 389-400.

Dannenberg, M.P. and E.K. Wise. 2017. Shifting Pacific storm tracks as stressors to ecosystems of western North America. Glob. Change Biol. 23(11): 4896-4906. doi:10.1111/gcb.13748.

De Kauwe, M.G., T.F. Keenan, B.E. Medlyn, I.C. Prentice and C. Terrer. 2016. Satellite-based estimates underestimate the effect of $\mathrm{CO}_{2}$ fertilization on net primary productivity. Nat. Clim. Change 6(10): 892-893. doi:10.1038/nclimate3105.

DeBenedetti, S.H. and D.J. Parsons. 1979. Natural fire in subalpine meadows: A case description from the Sierra Nevada. J. For. 77(8): 477-479. doi:10.1093/jof/77.8.477.

Del Grosso, S., W. Parton, T. Stohlgren, D. Zheng, D. Bachelet, S. Prince, K. Hibbard and R. Olson. 2008. Global potential net primary production predicted from vegetation class, precipitation, and temperature. Ecology 89(8): 2117-2126. doi:10.1890/07-0850.1.

DeRose, R.J. and J.N. Long. 2012. Drought-driven disturbance history characterizes a southern Rocky Mountain subalpine forest. Can. J. For. Res. 42(9): 1649-1660. doi:10.1139/x2012-102.
Dodson, E.K. and H.T. Root. 2013. Conifer regeneration following stand-replacing wildfire varies along an elevation gradient in a ponderosa pine forest, Oregon, USA. For. Ecol. Manag. 302: 163-170. doi:10.1016/j.foreco.2013.03.050.

Doerr, S.H. and C. Santín. 2016. Global trends in wildfire and its impacts: Perceptions versus realities in a changing world. Phil. Trans. R. Soc. 371(1696): 20150345. doi:10.1098/rstb.2015.0345.

Dunwiddie, P.W. 1977. Recent tree invasion of subalpine meadows in the Wind River Mountains, Wyoming. Arct. Alp. Res. 9(4): 393 399. doi:10.1080/00040851.1977.12003932.

Dyer, J.M. and K.E. Moffett. 1999. Meadow invasion from highelevation spruce-fir forest in south-central New Mexico. Southwest. Nat. 44(4): 444-456. doi:10.2307/3672342.

Elliott, G.P. and W.L. Baker. 2004. Quaking aspen (Populus tremuloides Michx.) at treeline: A century of change in the San Juan Mountains, Colorado, USA. J. Biogeogr. 31(5): 733-745. doi:10.1111/j.1365-2699.2004.01064.x.

Franklin, J.F., W.H. Moir, G.W. Douglas and C. Wiberg. 1971. Invasion of subalpine meadows by trees in the Cascade Range, Washington and Oregon. Arct. Alp. Res. 3(3): 215-224.

Frey, B.R., V.J. Lieffers, E.H. Hogg and S.M. Landhäusser. 2004. Predicting landscape patterns of aspen dieback: Mechanisms and knowledge gaps. Can. J. For. Res. 34(7): 1379-1390. doi:10.1139/ x04-062.

Gedalof, Z. and A.A. Berg. 2010. Tree ring evidence for limited direct $\mathrm{CO}_{2}$ fertilization of forests over the $20^{\text {th }}$ century. Glob. Biogeochem. Cycles 24(3): GB3027. doi:10.1029/2009gb003699.

Graumlich, L.J., L.B. Brubaker and C.C. Grier. 1989. Long-term trends in forest net primary productivity: Cascade Mountains, Washington. Ecol. 70(2): 405-410. doi:10.2307/1937545.

Gray, S.T., J.L. Betancourt, C.L. Fastie and S.T. Jackson. 2003. Patterns and sources of multidecadal oscillations in drought-sensitive tree-ring records from the central and southern Rocky Mountains. Geophys. Res. Lett. 30(6): 1316. doi:10.1029/2002gl016154.

Greve, P., B. Orlowsky, B. Mueller, J. Sheffield, M. Reichstein and S.I. Seneviratne. 2014. Global assessment of trends in wetting and drying over land. Nat. Geosci. 7(10): 716-721. doi:10.1038/ngeo2247. Griffin, D. and K.J. Anchukaitis. 2014. How unusual is the 20122014 California drought? Geophys. Res. Lett. 41(24): 9017-9023. doi:10.1002/2014gl062433.

Guarín, A. and A.H. Taylor. 2005. Drought triggered tree mortality in mixed conifer forests in Yosemite National Park, California, USA. For. Ecol. Manag. 218(1-3): 229-244. doi:10.1016/j.foreco.2005.07.014. Guay, K.C., P.S.A. Beck, L.T. Berner, S.J. Goetz, A. Baccini and W. Buermann. 2014. Vegetation productivity patterns at high northern latitudes: A multi-sensor satellite data assessment. Global Change Biol. 20(10): 3147-3158. doi:10.1111/gcb.12647.

Guiterman, C.H., E.Q. Margolis, C.D. Allen, D.A. Falk and T.W. Swetnam. 2018. Long-term persistence and fire resilience of oak shrubfields in dry conifer forests of northern New Mexico. Ecosyst. 21(5): 943-959. doi:10.1007/s10021-017-0192-2.

Hagmann, R.K., J.F. Franklin and K.N. Johnson. 2013. Historical structure and composition of ponderosa pine and mixed-conifer forests in south-central Oregon. For. Ecol. Manag. 304: 492-504. doi:10.1016/j.foreco.2013.04.005.

Halpern, C.B., J.A. Antos, J.M. Rice, R.D. Haugo and N.L. Lang. 2010. Tree invasion of a montane meadow complex: Temporal trends, spatial patterns, and biotic interactions. J. Veg. Sci. 21(4): 717-732. doi:10.1111/j.1654-1103.2010.01183.x.

Hanberry, B.B. and M.H. Hansen. 2015. Latitudinal range shifts of tree species in the United States across multi-decadal time scales. Basic Appl. Ecol. 16(3): 231-238. doi:10.1016/j.baae.2015.02.002.

Haugo, R.D. and C.B. Halpern. 2010. Tree age and tree species shape positive and negative interactions in a montane meadow. Bot. 88(5): 488-499. doi:10.1139/b10-018. 
Helms, J.A. 1987. Invasion of Pinus contorta var. Murrayana (Pinaceae) into mountain meadows at Yosemite National Park, California. Madroña 34(2): 91-97. https://www.jstor.org/stable/ 41424621.

Hember, R.A., W.A. Kurz and N.C. Coops. 2017. Relationships between individual-tree mortality and water-balance variables indicate positive trends in water stress-induced tree mortality across North America. Glob. Change Biol. 23(4): 1691-1710. doi:10.1111/gcb.13428.

Hughes, M.K. and G. Funkhouser. 2003. Frequency-dependent climate signal in upper and lower forest border tree rings in the mountains of the Great Basin. Clim. Change 59(1-2): 233-244. doi:10.1023/a:1024464909332.

Jakubos, B. and W.H. Romme. 1993. Invasion of subalpine meadows by lodgepole pine in Yellowstone National Park, Wyoming, USA. Arct. Alp. Res. 25(4): 382-390. doi:10.1080/00040851. 1993.12003024.

Jiang, C., Y. Ryu, H. Fang, R. Myneni, M. Claverie and Z. Zhu. 2017. Inconsistencies of interannual variability and trends in longterm satellite leaf area index products. Glob. Change Biol. 23(10): 4133-4146. doi:10.1111/gcb.13787.

Jump, A.S., P. Ruiz-Benito, S. Greenwood, C.D. Allen, T. Kitzberger, R. Fensham, J. Martínez-Vilalta and F. Lloret. 2017. Structural overshoot of tree growth with climate variability and the global spectrum of drought-induced forest dieback. Glob. Change Biol. 23(9): 3742-3757. doi:10.1111/gcb.13636.

Kadonaga, L.K., O. Podlaha and M.J. Whiticar. 1999. Time series analyses of tree ring chronologies from Pacific North America: Evidence for sub-century climate oscillations. Chem. Geol. 161(1-3): 339-363. doi:10.1016/s0009-2541(99)00094-7.

Kashian, D.M., W.H. Romme, D.B. Tinker, M.G. Turner and M.G. Ryan. 2013. Postfire changes in forest carbon storage over a 300-year chronosequence of Pinus contorta-dominated forests. Ecol. Monogr. 83(1): 49-66. doi:10.1890/11-1454.1.

Kim, Y., J.S. Kimball, K. Zhang and K.C. McDonald. 2012. Satellite detection of increasing Northern Hemisphere non-frozen seasons from 1979 to 2008: Implications for regional vegetation growth. Remote Sens. Environ. 121: 472-487. doi:10.1016/ j.rse.2012.02.014.

Kirby, M.E., S.J. Feakins, C.A. Hiner, J. Fantozzi, S.R.H. Zimmerman, T. Dingemans and S.A. Mensing. 2014. Tropical Pacific forcing of Late-Holocene hydrologic variability in the coastal southwest United States. Quat. Sci. Rev. 102: 27-38. doi:10.1016/j.quascirev. 2014.08.005.

Klasner, F.L. and D.B. Fagre. 2002. A half century of change in alpine treeline patterns at Glacier National Park, Montana, USA Arct. Antarct. Alp. Res. 34(1): 49-56. doi:10.1080/15230430. 2002.12003468 .

Klimaszewski-Patterson, A., P.J. Weisberg, S.A. Mensing and R.M. Scheller. 2018. Using paleolandscape modeling to investigate the impact of Native American-set fires on pre-Columbian forests in the southern Sierra Nevada, California, USA. Ann. Amer. Assoc Geograph. 108(6): 1635-1654. doi:10.1080/24694452.2018.1470922. Lee, E.H., P.A. Beedlow, R.S. Waschmann, D.T. Tingey, C. Wickham, S. Cline, M. Bollman and C. Carlile. 2016. Douglas-fir displays a range of growth responses to temperature, water, and Swiss needle cast in western Oregon, USA. Agric. For. Meteorol. 221: 176188. doi:10.1016/j.agrformet.2016.02.009.

Loehle, C. 2018. Model-based forecasts of North American forest growth: A review. Amer. J. Clim. Change 7(4): 519-547. doi:10.4236/ajcc.2018.74032.

Loehle, C. In Review. Forest growth changes in the eastern United States. Forest. Chron.

Loehle, C. and K. Solarik. Forest growth changes in Canada. Forest. Chron. 95(3): 183-195.
Loehle, C., C. Idso and T.B. Wigley. 2016. Physiological and ecological factors influencing recent trends in United States forest health responses to climate change. For. Ecol. Manag. 363: 179-189. doi:10.1016/j.foreco.2015.12.042.

Margolis, E.Q. and S.B. Malevich. 2016. Historical dominance of low-severity fire in dry and wet mixed-conifer forest habitats of the endangered terrestrial Jemez Mountains salamander (Plethodon neomexicanus). For. Ecol. Manag. 375: 12-26. https://dx.doi.org/ 10.1016/j.foreco.2016.05.011.

Mast, J.N. and J.J. Wolf. 2004. Ecotonal changes and altered tree spatial patterns in lower mixed-conifer forests, Grand Canyon National Park, Arizona, USA. Landsc. Ecol. 19(2): 167-180. doi:10.1023/b:land.0000021718.20058.36.

McCabe, G.J. and M.D. Dettinger. 2002. Primary modes and predictability of year-to-year snowpack variations in the western United States from teleconnections with Pacific Ocean climate. J. Hydrometeorol. 3(1): 13-25. doi:10.1175/1525-7541(2002)003 $<0013$ :pmapoy>2.0.co;2.

McDowell, N.G. and C.D. Allen. 2015. Darcy's law predicts widespread forest mortality under climate warming. Nat. Clim. Change 5(7): 669-672. doi:10.1038/nclimate2641.

McDowell, N.G. et al. 2016. Multi-scale predictions of massive conifer mortality due to chronic temperature rise. Nat. Clim. Change 6(3): 295-300. doi:10.1038/nclimate2873.

McIntyre, P.J., J.H. Thorne, C.R. Dolanc, A.L. Flint, L.E. Flint, M. Kelly and D.D. Ackerly. 2015. Twentieth-century shifts in forest structure in California: Denser forests, smaller trees, and increased dominance of oaks. Proc. Natl. Acad. Sci. USA 112(5): 1458-1463. doi:10.1073/pnas.1410186112.

McKenzie, D., A.E. Hessl and D.L. Peterson. 2001. Recent growth of conifer species of western North America: Assessing spatial patterns of radial growth trends. Can. J. For. Res. 31(3): 526-538. doi:10.1139/x00-191.

Millar, C.I., R.D. Westfall and D.L. Delany. 2007. Response of high-elevation limber pine (Pinus flexilis) to multiyear droughts and 20th-century warming, Sierra Nevada, California, USA. Can. J. For. Res. 37(12): 2508-2520. doi:10.1139/X07-097.

Millar, C.I., R.D. Westfall, D.L. Delany, J.C. King and L.J. Graumlich. 2004. Response of subalpine conifers in the Sierra Nevada, California, USA, to $20^{\text {th }}$-century warming and decadal climate variability. Arct. Antarct. Alp. Res. 36(2): 181-200. doi:10.1657/1523-0430(2004)036[0181:roscit]2.0.co;2.

Millar, C.I., R.D. Westfall, D.I. Delany, A.L. Flint and L.E. Flint. 2015. Recruitment patterns and growth of high-elevation pines in response to climatic variability (1883-2013), in the western Great Basin, USA. Can. J. For. Res. 45(10): 1299-1312. doi:10.1139/cjfr2015-0025.

Millar, C.I., R.D. Westfall, D.L. Delany, M.J. Bokach, A.L. Flint and L.E. Flint. 2012. Forest mortality in high-elevation whitebark pine (Pinus albicaulis) forests of eastern California, USA: Influence of environmental context, bark beetles, climatic water deficit, and warming. Can. J. For. Res. 42(4): 749-765. doi:10.1139/x2012-031.

Moir, W.H., S.G. Rochelle and A.W. Schoettle. 1999. Microscale patterns of tree establishment near upper treeline, Snowy Range, Wyoming, USA. Arct. Antarct. Alp. Res. 31(4): 379-388. doi:10.1080/15230430.1999.12003322.

Monleon, V.J. and H.E. Lintz. 2015. Evidence of tree species' range shifts in a complex landscape. PLoS One 10(1): e0118069. doi:10.1371/journal.pone.0118069.

Moore, M.M. and D.W. Huffman. 2004. Tree encroachment on meadows of the Northern Rim, Grand Canyon National Park, Arizona, USA. Arct. Antarct. Alp. Res. 36(4): 474-483. doi:10.1657/ 1523-0430(2004)036[0474:teomot]2.0.co;2.

Mote, P.W., S. Li, D.P. Lettenmaier, M. Xiao and R. Engel. 2018. Dramatic declines in snowpack in the western US. Clim. Atmos. Sci. 1(1): 2. doi:10.1038/s41612-018-0012-1. 
Nehrbass-Ahles, C., F. Babst, S. Klesse, M. Nötzli, O. Bouridaud, R. Neukom, M. Dobbertin and D. Frank. 2014. The influence of sampling design on tree-ring-based quantification of forest growth. Glob. Change Biol. 20(9): 2867-2885. doi:10.1111/gcb.12599.

Nelson, M.D. and G.A. Reams. 2017. Is the area of US forests increasing or decreasing? For. Source 22: 16-17, 21. www.nxtbook. com/nxtbooks/saf/forestrysource_201705/index.php\#/1.

O'Connor, C.D., D.A. Falk, A.M. Lynch and T.W. Swetnam. 2014. Fire severity, size, and climate associations diverge from historical precedent along an ecological gradient in the Pinaleño Mountains, Arizona, USA. For. Ecol. Manag. 329: 264-278. https://dx.doi.org/10.1016/j.foreco.2014.06.032.

Pederson, N. et al. 2015. Climate remains an important driver of post-European vegetation change in the eastern United States. Glob. Change Biol. 21(6): 2105-2110. doi:10.1111/gcb.12779.

Peñuelas, J. et al. 2013. Evidence of current impact of climate change on life: A walk from genes to the biosphere. Glob. Change Biol. 19(8): 2303-2338. doi:10.1111/gcb.12143.

Perkins, D.L. and T.W. Swetnam. 1996. A dendroecological assessment of whitebark pine in the Sawtooth - Salmon River region, Idaho. Can. J. For. Res. 26(12): 2123-2133. doi:10.1139/x26-241.

Pretzsch, H. et al. 2017. Climate change accelerates growth of urban trees in metropolises worldwide. Sci. Rep. 7(1): 15403. doi:10.1038/s41598-017-14831-w.

Reed, C.C., A.P. Ballantyne, L.A. Cooper and A. Sala. 2018. Limited evidence for $\mathrm{CO}_{2}$-related growth enhancement in northern Rocky Mountain lodgepole pine populations across climate gradients. Glob. Change Biol. 24(9): 3922-3937. doi:10.1111/gcb.14165. Reilly, M.J. and T.A. Spies. 2016. Disturbance, tree mortality, and implications for contemporary regional forest change in the Pacific Northwest. For. Ecol. Manag. 374: 102-110. doi:10.1016/j.foreco. 2016.05.002

Rice, J.M., C.B. Halpern, J.A. Antos and J.A. Jones. 2012. Spatiotemporal patterns of tree establishment are indicative of biotic interactions during early invasion of a montane meadow. Plant Ecol. 213(4): 555-568. doi:10.1007/s11258-012-0021-9.

Robeson, S.M. 2015. Revisiting the recent California drought as an extreme value. Geophys. Res. Lett. 42(16): 6771-6779. doi:10.1002/ $2015 \mathrm{gl064593.}$

Roccaforte, J.P., P.Z. Fulé, W.W. Chancellor and D.C. Laughline. 2012. Woody debris and tree regeneration dynamics following severe wildfires in Arizona ponderosa pine forests. Can. J. For. Res. 42(3): 593-604. doi:10.1139/x2012-010.

Rochefort, R.M., R.L. Little, A. Woodward and D.L. Peterson. 1994. Changes in sub-alpine tree distribution in western North America: A review of climatic and other causal factors. Holocene 4(1): 89-100. doi:10.1177/095968369400400112.

Roesch, F.A. and P.C. Van Deusen. 2010. Anomalous diameter distribution shifts estimated from FIA inventories through time. Forestry 83(3): 269-276. doi:10.1093/forestry/cpq009.

Rother, M.T. and T.T. Veblen. 2016. Limited conifer regeneration following wildfires in dry ponderosa pine forests of the Colorado Front Range. Ecosphere 7(12): e01594. doi:10.1002/ecs2.1594.

Salzer, M.W., M.K. Hughes, A.G. Bunn and K.F. Kipfmueller. 2009. Recent unprecedented tree-ring growth in bristlecone pine at the highest elevations and possible causes. Proc. Natl. Acad. Sci. USA 106(48): 20348-20353. doi:10.1073/pnas.0903029106.

Savage, M., J.N. Mast and J.J. Feddema. 2013. Double whammy: High-severity fire and drought in ponderosa pine forests of the Southwest. Can. J. For. Res. 43(6): 570-583. https://dx.doi.org/ 10.1139/cjfr-2012-0404.

Schulte-Uebbing, L. and W. de Vries. 2018. Global-scale impacts of nitrogen deposition on tree carbon sequestration in tropical, temperate, and boreal forests: A meta-analysis. Glob. Change Biol. 24(2): e416-e431. doi:10.1111/gcb.13862.
Shankman, D. and C. Daly. 1988. Forest regeneration above tree limit depressed by fire in the Colorado Front Range. Bull. Torrey Bot. Club 115(4): 272-279. https://www.jstor.org/stable/2996159.

Sibold, J.S. and T.T. Veblen. 2006. Relationships of subalpine forest fires in the Colorado Front Range with interannual and multidecadal-scale climatic variation. J. Biogeogr. 33(5): 833-842. doi:10.1111/j.1365-2699.2006.01456.x.

Siler, N., C. Proistosescu and S. Po-Chedley. 2019. Natural variability has slowed the decline in western US snowpack since the 1980s. Geophys. Res. Lett. 46(1): 346-355. doi:10.1029/ $2018 \mathrm{gl081080}$

Singleton, M.P., A.E. Thode, A.J. Sánchez Meador and J.M. Iniguez. 2019. Increasing trends in high-severity fire in the southwestern USA from 1984 to 2015. For. Ecol. Manag. 433: 709-719. doi:10.1016/j.foreco.2018.11.039.

Smith, J.M., J. Paritsis, T.T. Veblen and T.B. Chapman. 2015. Permanent forest plots show accelerating tree mortality in subalpine forests of the Colorado Front Range from 1982 to 2013. For. Ecol. Manag. 341: 8-17. doi:10.1016/j.foreco.2014.12.031.

Smith, W.K., S.C. Reed, C.C. Cleveland, A.P. Ballantyne, W.R.L. Anderegg, W.R. Wieder, Y.Y. Liu and S.W. Running. 2016. Large divergence of satellite and Earth system model estimates of global terrestrial $\mathrm{CO}_{2}$ fertilization. Nat. Clim. Change 6(3): 306-310. doi:10.1038/nclimate2879.

Smithers, B.V., M.P. North, C.I. Millar and A.M. Latimer. 2018. Leap frog in slow motion: Divergent responses of tree species and life stages to climatic warming in Great Basin subalpine forests. Glob. Change Biol. 24(2): e442-e457. doi:10.1111/gcb.13881.

Soulé, P.T. and P.A. Knapp. 2006. Radial growth rate increases in naturally occurring ponderosa pine trees: A late-20th century $\mathrm{CO}_{2}$ fertilization effect? New Phytol. 171(2): 379-390. doi:10.1111/ j.1469-8137.2006.01746.x.

Steinman, B.A. et al. 2014. Ocean-atmosphere forcing of centennial hydroclimate variability in the Pacific Northwest. Geophys. Res. Lett. 41(7): 2553-2560. doi:10.1002/2014gl059499.

Stephens, S.L., J.M. Lydersen, B.M. Collins, D.L. Fry and M.D. Meyer. 2015. Historical and current landscape-scale ponderosa pine and mixed conifer forest structure in the southern Sierra Nevada. Ecosphere 6(5): 79. doi:10.1890/es14-00379.1.

Stevens, N., C.E.R. Lehmann, B.P. Murphy and G. Durigan. 2017. Savanna woody encroachment is widespread across three continents. Glob. Change Biol. 23(1): 235-244. doi:10.1111/gcb.13409.

Stevens-Rumann, C.S., K.B. Kemp, P.E. Higuere, B.J. Harvey, M.T. Rother, D.C. Donato, P. Morgan and T.T. Veblen. 2018. Evidence for declining forest resilience to wildfires under climate change. Ecol. Lett. 21(2): 243-252. doi:10.1111/ele.12889.

Stine, P. et al. 2014. The ecology and management of moist mixedconifer forests in eastern Oregon and Washington: A synthesis of the relevant biophysical science and implications for future land management. USDA For. Serv. Gen. Tech. Rept. PNW-GTR-897. www.fs.fed.us/pnw/pubs/pnw_gtr897.pdf

Swetnam, T.W., J. Farella, C.I. Roos, M.J. Liebmann, D.A. Falk and C.D. Allen. 2016. Multiscale perspectives of fire, climate and humans in western North America and the Jemez Mountains, USA. Phil. Trans. R. Soc. B 371(1696): 20150168. https://dx.doi.org/ 10.1098/rstb.2015.0168.

Taylor, A.H. 1990. Tree invasion in meadows of Lassen Volcanic National Park, California. Prof. Geogr. 42(4): 457-470. doi:10.1111/ j.0033-0124.1990.00457.x.

Taylor, A.H. 1995. Forest expansion and climate change in the mountain hemlock (Tsuga mertensiana) zone, Lassen Volcanic National Park, California, USA. Arct. Alp. Res. 27(3): 207-216. doi:10.1080/00040851.1995.12003115.

Taylor, A.H., V. Trouet, C.N. Skinner and S. Stephens. 2016. Socioecological transitions trigger fire regime shifts and modulate 
fire-climate interactions in the Sierra Nevada, USA, 1600-2015 CE. Proc. Natl. Acad. Sci. USA 113(48): 13684-13689. doi:10.1073/pnas. 1609775113.

Thorpe, H.C. and L.D. Daniels. 2012. Long-term trends in tree mortality rates in the Alberta foothills are driven by stand development. Can. J. For. Res. 42(9): 1687-1696. doi:10.1139/x2012-104.

Vale, T.R. 1978. Tree invasion of Cinnabar Park in Wyoming. Am. Midl. Nat. 100(2): 277-284. https://www.jstor.org/stable/2424827.

Vale, T.R. 1981. Ages of invasive trees in Dana Meadows, Yosemite National Park, California. Madroño 28(1): 45-47. www.jstor.org/ stable/41424293.

Van Mantgem, P.J. et al. 2009. Widespread increase in tree mortality rates in the western United States. Science 323(5913): 521-524. doi:10.1126/science.1165000.

Vankat, J.L. 2017. Post-1935 changes in pinyon-juniper persistent woodland on the South Rim of Grand Canyon National Park, Arizona, USA. For. Ecol. Manag. 394: 73-85. doi:10.1016/ j.foreco.2017.03.018.

Veblen, T.T. and D.C. Lorenz. 1991. The Colorado Forest Range: A century of ecological change. University of Utah Press, Salt Lake City.

Voelker, S.L., A.G. Merschel, F.C. Meinzer, D.E. Ulrich, T.A. Spies and C.J. Still. 2019. Fire deficits have increased drought-sensitivity in dry conifer forests; fire frequency and tree-ring carbon isotope evidence from central Oregon. Glob. Change. Biol. 25(4): 1247-1262. doi:10.1111/gcb.14543.

Wang, R. et al. 2017. Global forest carbon uptake due to nitrogen and phosphorus deposition from 1850 to 2100. Glob. Change Biol. 23(11): 4854-4872. doi:10.1111/gcb.13766.

Weiss, J.L., C.L. Castro and J.T. Overpeck. 2009. Distinguishing pronounced droughts in the southwestern United States: Seasonality and effects of warmer temperatures. J. Clim. 22(22): 5918-5932. doi:10.1175/2009jcli2905.1.
Williams, A.P., C.D. Allen, C.I. Millar, T.W. Swetnam, J. Michaelsen, C.J. Still and S.W. Leavitt. 2010. Forest responses to increasing aridity and warmth in the southwestern United States. Proc. Natl. Acad. Sci. USA 107(50): 21289-21294. doi:10.1073/ pnas.0914211107.

Woodhouse, C.A. 2003. A 431-yr reconstruction of western Colorado snowpack from tree rings. J. Clim. 16(10): 1551-1561.

Woolley, T.J., M.E. Harmon and K.B. O'Connell. 2015. Interannual variability and spatial coherence of net primary productivity across a western Oregon Cascades landscape. For. Ecol. Manag. 335: 60-70. doi:10.1016/j.foreco.2014.09.028.

Worrall, J.J., S.B. Marchetti, L. Egeland, R.A. Mask, T. Eager and B. Howell. 2010. Effects and etiology of sudden aspen decline in southwestern Colorado, USA. For. Ecol. Manag. 260(5): 638-648. doi:10.1016/j.foreco.2010.05.020.

Worrall, J.J., L. Egeland, T. Eager, R.A. Mask, E.W. Johnson, P.A. Kemp and W.D. Sheppard. 2008. Rapid mortality of Populus tremuloides in southwestern Colorado, USA. For. Ecol. Manag. 255(3-4): 686-696. doi:10.1016/j.foreco.2007.09.071.

Worrall, J.J., G.E. Rehfeldt, A. Hamann, E.H. Hogg, S.B. Marchetti, M. Michaelian and L.K. Gray. 2013. Recent declines of Populus tremuloides in North America linked to climate. For. Ecol. Manag. 299: 35-51. doi:10.1016/j.foreco.2012.12.033.

Young, D.J.N., J.T. Stevens, J.M. Earles, J. Moore, A. Ellis, A.L. Jirka and A.M. Latimer. 2017. Long-term climate and competition explain forest mortality patterns under extreme drought. Ecol. Lett. 20(1): 78-86. doi:10.11118ele12711. 